\title{
Emergence of linezolid-resistant Staphylococcus epidermidis in the tertiary children's hospital in Cracow, Poland
}

\author{
Maja Kosecka-Strojek ${ }^{1}$ - Ewa Sadowy ${ }^{2}$ - Iwona Gawryszewska ${ }^{2}$. Joanna Klepacka ${ }^{3} \cdot$ Tomasz Tomasik $^{3}$. \\ Michal Michalik $^{4} \cdot$ Waleria Hryniewicz $^{5} \cdot$ Jacek Miedzobrodzki $^{1}$
}

Received: 28 December 2019 / Accepted: 1 April 2020 / Published online: 29 April 2020

(C) The Author(s) 2020

\begin{abstract}
Coagulase-negative staphylococci, ubiquitous commensals of human skin, and mucous membranes represent important pathogens for immunocompromised patients and neonates. The increasing antibiotic resistance among Staphylococcus epidermidis is an emerging problem worldwide. In particular, the linezolid-resistant S. epidermidis (LRSE) strains are observed in Europe since 2014. The aim of our study was to genetically characterize 11 LRSE isolates, recovered mostly from blood in the University Children's Hospital in Krakow, Poland, between 2015 and 2017. For identification of the isolates at the species level, we used $16 \mathrm{~S}$ rRNA sequencing and RFLP of the $s a o C$ gene. Isolates were characterized phenotypically by determining their antimicrobial resistance patterns and using molecular methods such as PFGE, MLST, SCCmec typing, detection of the ica operon, and analysis of antimicrobial resistance determinants. All isolates were multidrug-resistant, including resistance to methicillin, and exhibited so-called PhLOPS A phenotype. In PFGE, all isolates (excluding one from a catheter) represented identical patterns, were identified as ST2, and harbored the ica operon, responsible for biofilm formation. Linezolid resistance was associated with acquisition of A157R mutation in the ribosomal protein L3 and the presence of $c f r$ gene. All isolates revealed new SCCmec cassette element composition. Recently, pediatric patients with serious staphylococcal infections are often treated with linezolid. The increasing linezolid resistance in bacterial strains becomes a real threat for patients, and monitoring such infections combined with surveillance and infection prevention programs is very important to decrease number of linezolid-resistant staphylococcal strains.
\end{abstract}

Keywords Staphylococci $\cdot$ Antibiotic resistance $\cdot$ Infections $\cdot$ ICU

Maja Kosecka-Strojek and Ewa Sadowy contributed equally to this work.

Jacek Miedzobrodzki

jacek.miedzobrodzki@uj.edu.pl

1 Department of Microbiology, Faculty of Biochemistry, Biophysics and Biotechnology, Jagiellonian University, Gronostajowa 7, 30-387 Krakow, Poland

2 Department of Molecular Microbiology, National Medicines Institute, Warsaw, Poland

3 Department of Clinical Microbiology, Children's University Hospital, Jagiellonian University, Krakow, Poland

4 MML Medical Centre, Warsaw, Poland

5 Department of Epidemiology and Clinical Microbiology, National Medicines Institute, Warsaw, Poland

\section{Introduction}

Coagulase-negative staphylococci (CoNS) ubiquitously colonize human skin and mucosal membranes, and due to this fact, they were for a long time considered harmless commensals [1]. Nowadays, however, they are increasingly important etiologic agents of hospital-acquired infections (HAIs), including central line-associated bloodstream infections (CLABSIs) and surgical-site infections (SSIs). Among human CoNS, Staphylococcus epidermidis represents the most frequently isolated species [2]. The increasing prevalence of antibiotic-resistant CoNS from nosocomial infections have been reported in Europe for some time [3-6], including especially worrisome methicillin-resistant S. epidermidis (MRSE) [7]. Since 2000, linezolid, a representative of the oxazolidynones has become an important addition in treatment for uncomplicated and complicated skin and skin structure infections and hospital- and 
community-acquired pneumonia caused by Gram-positive pathogens [8]. Shortly after the introduction into hospital practice, the first case of linezolid-resistant Staphylococcus aureus was reported in the USA in 2001 [9]. Linezolidresistant $S$. epidermidis (LRSE) are increasingly observed in European countries, such as Portugal, Germany, Greece, Italy, Ireland, and France [10-17]. Linezolid resistance determinants may be acquired by staphylococci due to mutations selected during prolonged linezolid therapy and by horizontal gene transfer [18-21]. The G2576T mutation in the loop V of $23 \mathrm{~S}$ rRNA is the principal determinant of the resistance; however, other mutations such as C2190T, T2502A, C2532T, and G2603T are observed as well [11, 22-24]. Mutations in the genes of ribosomal proteins L3 ( $r p l C$ gene), L4 ( $r p l D$ gene), and L22 ( $r p l V$ gene) are also relatively frequently encountered among LRSE [8]. As reviewed by Mendes et al. [8], the alterations in L3 and L4 as a resistance mechanism appeared later in time and the complexity and number of such alterations in LRSE increased since 2014. The A157R modification in L3 was observed in the USA and Italy up to date [8]. Transferable genes conferring linezolid resistance in staphylococci include the $c f r$ gene encoding ribosomal methyltransferase gene and the optrA and poxtA genes of ribosomal protection proteins [25-28]. Among these, only $c f r$ was reported among LRSE so far [29]. Next emerging problem is that linezolid and methicillin resistance are often combined, so it is also important to characterize the SCCmec cassette elements in such isolates [16, 30-31].

Here, we present a report on a possible LRSE spread in the University Children's Hospital (UCH) in Krakow, Poland, between 2015 and 2017. The aim of this study was to genetically characterize the LRSE strains, determine their clonal relationships, linezolid resistance mechanisms and refer the results to patients' characteristics.

\section{Materials and methods}

\section{Bacterial isolates}

The study included 11 LRSE clinical isolates recovered between 2015 and 2017 from the UCH in Krakow from 10 pediatric patients aged from 23 days to 11 months. Nine isolates were recovered from blood (including two isolates from the same patient), one from a throat and one from a central venous catheter. All isolates were recovered after at least $48 \mathrm{~h}$ after admission to the unit. Linezolid resistance was detected in the hospital laboratory based on disc-diffusion method (linezolid $(30 \mu \mathrm{g}))$. The preliminary identification of isolates was performed with BD Phoenix ${ }^{\mathrm{TM}}$ system (Becton Dickinson, Franklin Lakes, NJ, USA).

\section{Genomic DNA extraction}

For genomic DNA extraction, isolates were grown for 18$20 \mathrm{~h}$ at $37^{\circ} \mathrm{C}$ on blood agar plates. A full inoculation loop of $10 \mu \mathrm{l}$ of bacterial colonies was homogenized with a TissueLyser II (Qiagen, Germantown, MD, USA). Total DNA was extracted by enzymatic lysis using the buffers and solutions provided with the DNeasy Blood and Tissue Kit (Qiagen, Germantown, MD, USA) according to manufacturer's instructions.

\section{Species identification}

All isolates were identified at the species level by sequencing of 16S rRNA as previously described [32] and PCR-RFLP of the $s a o C$ gene [33]. The 16S rRNA gene was amplified with slight modifications in PCR program: initial denaturation for 2 min at $94^{\circ} \mathrm{C}$, then followed by 25 cycles of denaturation at $94{ }^{\circ} \mathrm{C}$ for $30 \mathrm{~s}$, annealing at $58^{\circ} \mathrm{C}$ for $30 \mathrm{~s}$, and extension at $72{ }^{\circ} \mathrm{C}$ for $60 \mathrm{~s}$. The final extension was for $5 \mathrm{~min}$ at $72^{\circ} \mathrm{C}$. The PCR products were resolved by electrophoresis and purified using the DNA Clean \& Concentrator ${ }^{\mathrm{TM}_{-}} 5$ purification kit (Zymo Research, Irvine, CA, USA). Two hundred nanograms of PCR product was used for sequencing with the primers used for PCR amplification. The $s a o C$ gene was amplified with the set of seven primers described previously [33]. PCR products were digested separately using each enzyme from the set of restriction enzymes (TaiI, Tsp509I, AluI, and MseI (Thermo Fisher Scientific, Waltham, MA, USA)). The obtained restriction patterns were compared to $s a o C$ gene fingerprint of the reference S. epidermidis strain.

\section{Susceptibility testing}

Methicillin resistance was initially identified using cefoxitin disks $(30 \mu \mathrm{g})$ (Oxoid Ltd., Cambridge, UK), and the phenotype was further confirmed by the detection of the mecA gene [34]. MIC values for linezolid, ceftarolin, vancomycin, teicoplanin, dalbavancin, daptomycin, and fosfomycin were determined using the Etest method (bioMérieux, Marcy l'Etoile, France); MIC of ciprofloxacin was determined by a broth microdilution method according to the European Committee on Antimicrobial Susceptibility Testing (EUCAST; www.eucast.org); for rifampin, tetracycline, minocycline, tigecycline, chloramphenicol, and gentamicin, the disk-diffusion method was used following the EUCAST recommendations. The results were interpreted using the EUCAST criteria. The $S$. aureus strain ATCC 29213 was used as a control. Inducible clindamycin resistance was tested by placing the erythromycin and clindamycin double-disk test according to the EUCAST recommendations. 


\section{Molecular typing, analysis of antimicrobial resistance determinants, and detection of the ica operon}

The clonality of isolates was studied using the pulsed-field electrophoresis (PFGE) of SmaI-digested bacterial DNA embedded in agarose plugs, as described by others [35] and the multilocus sequence typing (MLST) [36]. To assign alleles and sequence types (STs) for allelic profiles, the S. epidermidis MLST website (https://pubmlst.org/ sepidermidis/; 24th October 2019, date last accessed) was used [37]. The SCCmec cassettes were typed with two independent methods as described previously by Milheirico et al. [38] and Kondo et al. [34] with USA300 3956/13 strain as a positive control for IV SCCmec cassette.

Detection of the $c f r$ and optrA genes was performed as previously, using strains from the laboratory collection as positive controls [39]. Presence of $a a c\left(6^{\prime}\right)$-Ie- $a p h\left(2^{\prime \prime}\right)$ and structure of $\operatorname{Tn} 4001$ were studied as described [40] with the control strains characterized previously [41]. For the poxtA, fexA, nor $A$, fos $B$ and the ica operon detection by PCR and for $r p l C, r p l D, r p l V$ and the 23S rRNA gene sequencing primers were designed in the current study (Table 1).

\section{Nucleotide sequence accession numbers}

The 16S rRNA gene sequences were annotated using the NCBI BankIt tool and deposited in GenBank under accession numbers: MN850509-MN850519.

\section{Results}

\section{Patient characteristics}

We evaluated 10 patients (newborns and infants) age 23 days to 11 months at the time of the LRSE isolation; weight 915 to $6400 \mathrm{~g}$ on the day of admission to UCH. Four patients were small for gestational age (SGA), and no data was available for 2 patients. All patients were transferred from five different hospitals in Krakow or Lesser Poland. With an exception of one patient, all patients had at least one birth defect (Table 2). After transfer to the UCH, patients were admitted to two different Intensive Care Units: ICU $1(n=8)$ and ICU $2(n=2)$. All patients had indwelling central venous catheters. During the hospitalization, nine patients were transferred to another ward once or twice. The infection due to LRSE was diagnosed within 7 to 331 day after hospital admission. All LRSE isolates were recovered after at least $48 \mathrm{~h}$ after admission to the unit so the criterion of HAI is fulfilled. Patients were diagnosed with sepsis, fever, oliguria, and chronic respiratory failure. All patients underwent from one to six surgery operations. The values of infectious markers such as leukocytosis, the Creactive protein (CRP), and procalcitonin (PCT) are presented in Table 2. At the time of LRSE isolation, six patients were treated with linezolid, but all patients were treated with linezolid at least once during hospitalization (Table 2). Figure 1 shows the time of patient hospitalization, LRSE detection, and date of patient discharge.

Table 1 Primers used in the study

\begin{tabular}{|c|c|}
\hline Gene & Sequence $\left(5^{\prime}-3^{\prime}\right)$ \\
\hline \multirow[t]{2}{*}{ poxtA } & TGCCCGTATTGGTTATCTCC \\
\hline & TTCCTGCTCTGCATTGACTG \\
\hline \multirow[t]{2}{*}{ fexA } & ATGACTCTGATGGGGCTGTC \\
\hline & CCTGCTCCAAGGTACAAAGC \\
\hline \multirow[t]{2}{*}{ norA } & CAAGGTTTTGCAGGTGGATTG \\
\hline & TGCTTCTTTACGGCGTGACTT \\
\hline \multirow[t]{2}{*}{ fos $B$} & AGGTGAGACCTCGGCCTAT \\
\hline & CTTTCAACCAGATATACCAATCTTCA \\
\hline \multirow[t]{4}{*}{$i c a$ operon } & CTGGTAAAGTCCGTCAATGGAA \\
\hline & TACCGTTGGATATTGCCTCTG \\
\hline & ATTGACAGTCGCTACGAAAAGAAA \\
\hline & ATCACTACCGGAAACAGCGAT \\
\hline \multirow[t]{2}{*}{ rplC } & AGGAGGTGGACTTTCGATGAC \\
\hline & TGCAATTTCCTCCTTTCGCTTC \\
\hline \multirow[t]{2}{*}{$r p l D$} & TAAGAAGCGAAAGGAGGAAATTG \\
\hline & ATTACGGGGCGCTTAAGAAC \\
\hline \multirow[t]{2}{*}{$r p l V$} & TTTCAGCATACCATTTTGCTTCC \\
\hline & TAAAGGACATGCAGCAGACG \\
\hline \multirow[t]{2}{*}{ 23S rRNA } & CGGCGGCCGTAACTATAACG \\
\hline & CAGCACTTATCCCGTCCATAC \\
\hline
\end{tabular}




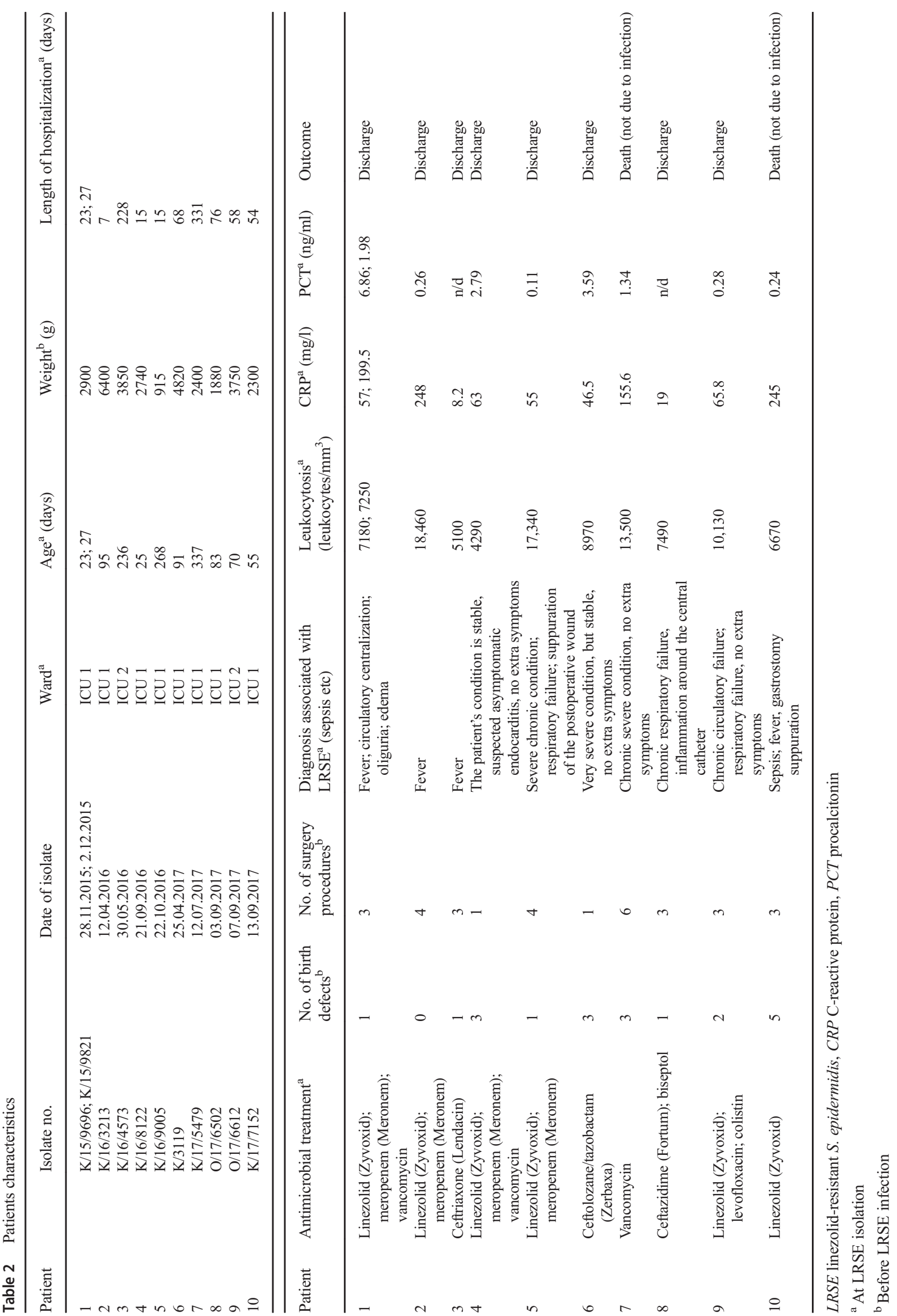


Fig. 1 Dates of patient hospitalization and isolation of LRSE

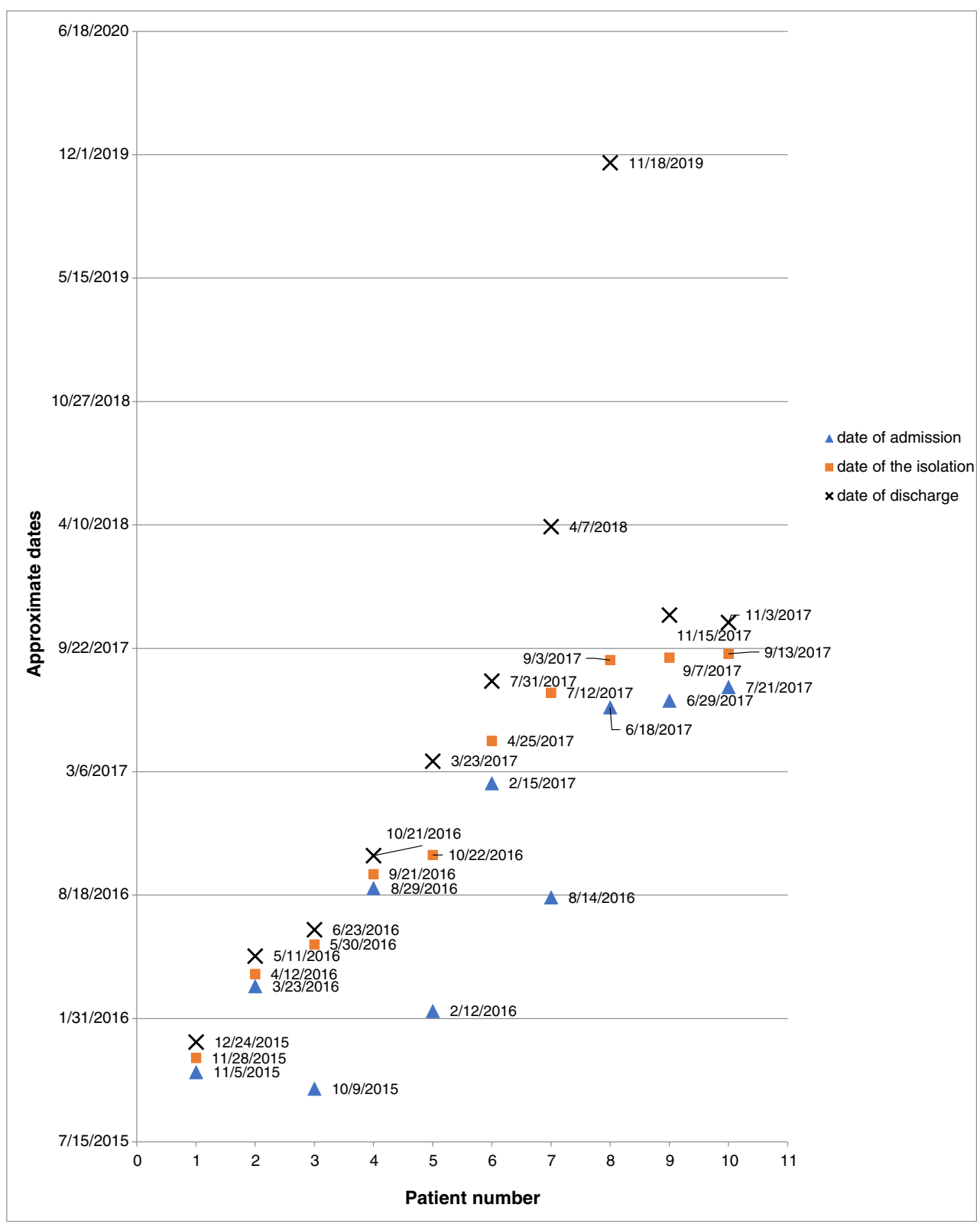

\section{Characteristics of isolates and species identification}

A total of 11 isolates from blood $(n=9)$, throat $(n=1)$, and central venous catheter $(n=1)$ collected from pediatric ICUs patients were investigated. Two isolates $(\mathrm{K} / 15 /$ 9696 and $\mathrm{K} / 15 / 9821$ ) were collected from the same patient, 23 and 27 days after hospitalization, respectively. The preliminary identification with $\mathrm{BD}$ Phoenix ${ }^{\mathrm{TM}}$ system identified seven isolates as $S$. epidermidis and three isolates as Staphylococcus hominis. The obtained 16S rRNA sequences, identical for all studied isolates, were analyzed using nucleotide BLAST (Basic Local Alignment Search Tool, http:/www.ncbi.nlm.nih.gov/BLAST/) and aligned to the reference sequences deposited in the GenBank and leBIBI databases. Using the previously described criteria for Staphylococcus identification at the species level [42-43], the best and the second-best species alignments were analyzed, and all isolates were identified as $S$. epidermidis. The identification as $S$. epidermidis was additionally confirmed with the $s a o C$ gene restriction analysis.

\section{Molecular typing and ica detection}

PFGE analysis included 10 isolates into the subtype $1 \mathrm{~A}$ and the remaining isolate from a catheter into the related pulsotype 1B. All isolates represented ST2 and harbored the ica operon. 


\section{Antimicrobial susceptibility and resistance determinants}

Eleven investigated isolates fully shared their antimicrobial susceptibility profiles. All isolates remained susceptible to vancomycin, teicoplanin, daptomycin, ceftaroline, tetracycline, minocycline, tigecycline, rifampin, and erythromycin. All isolates showed high resistance to linezolid (MIC above $256 \mathrm{mg} / \mathrm{L}$ ) together with resistance to chloramphenicol and clindamycin, consistent with the presence of $c f r$, rendering so-called PhLOPS A phenotype [44]. No inducible clindamycin resistance was detected. The chloramphenicolresistance gene, $f e x A$, was also observed in the whole group. Additionally, the isolates demonstrated the A157R change in their deduced amino acid sequences of the L3 protein. No changes occurred in the analyzed part of 23S rRNA genes and in the L4 and L22 protein genes. The isolates also demonstrated resistance to methicillin, ciprofloxacin, fosfomycin, and gentamicin, and in agreement with these phenotypes, all isolates were positive for mecA, norA, fos $B$, and aac(6')-Ieaph (2") located in the complete Tn 4001 transposon. Altogether, the isolates were resistant to six various classes of antimicrobials, i.e., they were multidrug resistant [45].

\section{SCCmec cassettes typing}

In both SCCmec typing methods, all isolates revealed new composition of the SCCmec cassette. All LRSE strains harbored: mecA, mecI, SCCmecIII J1, and $d c s$ genes which indicates the mixture of SCCmec type II and III cassette elements [38]. Despite the $d c s, m e c I$, and mecA genes, the SCCmec II cassette includes $k d p$ and $c c r B$ genes which were not detected in LRSE isolates. Although, all 11 isolates had SCCmecIII J1 gene which is a component of SCCmec III but they did not harbor RIF gene. The Kondo typing method [34] showed that all 11 LRSE isolates possessed class A of $m e c A$ gene and two $c c r$ complexes ( $c c r A B 3$ and $c c r A B 4$ ).

\section{Discussion}

Linezolid is an effective treatment for multidrug-resistant Gram-positive bacteria and despite its broad use for almost 20 years, it still exhibits excellent activity against staphylococci. Linezolid resistance among $S$. epidermidis remains uncommon worldwide but the increasing resistance in European countries such as Greece, Spain, Portugal, Italy, France, and Ireland has been reported [10-17]. The LRSE outbreaks occur occasionally and are mainly associated with ICUs [15]. Here, we describe the first emergence of LRSE and MRSE in Poland in a pediatric ICU. The emergence of LRSE strains is associated with an increased prior linezolid usage. In our hospital, linezolid was introduced into practice in 2005 . The first LRSE strain was isolated from cerebrospinal fluid at 12.01.2014 from the Oncology and Hematology Department. Since 2015, the increased number of LRSE was isolated from invasive infections with a highest number of isolates in 2017.

Pediatric patients are at particular risk of bacterial infections due to their immature immune system, and this risk is especially evident in premature newborns and babies undergoing medical procedures, such as surgery, presence of catheters, and prolonged/extensive antimicrobial treatment. Restriction of linezolid usage was associated with disappearance of the resistant strains from the affected ICU.

In Poland, the nosocomial $S$. epidermidis population is dominated by strains belonging to MLST clonal complex 2 (CC2) [http://eburst.mlst.net]. These clones are multiresistant, seem to persist in hospital environment, and evolve quickly due to mutations, recombination events, and frequent transmission of mobile genetic elements [46]. In the present study, all isolates belonged to ST2, a presumable ancestral type of CC2. In Germany, in 2015, Bender et al. described $12(33 \%)$ LRSE belonging to ST2 [11], O'Connor et al. described 9 isolates (100\%) as ST2 [13], and Barros et al. described one in a Portuguese hospital [10]. In 2018, Dortet et al. described an outbreak caused by ST2, ST5, and ST22 of LRSE in France [15]. In other European countries, five different STs were identified: (i) ST22 in Greece, Germany, and Spain [11-12, 16, 31]; (ii) ST23 in Italy and Germany [11, $14,16]$; (iii) ST83 in Italy [14]; and (iv and v) ST5 and ST168 in Germany $[11,16]$.

PFGE analyses are widely used for detection of the spread of a single clone at the local level [47], and we also applied this technique in our study. The restriction patterns of SmaI revealed two closely related PFGE types among isolates. Furthermore, all isolates shared the antimicrobial resistance phenotypes and determinants. Linezolid resistance was associated with acquisition of the A157R mutation in the ribosomal protein L3 and the presence of $c f r$ gene. Such L3 alterations were described previously to impact linezolid susceptibility [48-49]. As shown in other studies, the cfr gene can cooccur with other linezolid resistance mechanisms [26, 50-51]. Importantly, the presence of a highly similar cfr plasmids in different genetic backgrounds was confirmed [17], and their acquisition via horizontal gene transfer in LRSE has been shown $[11,14]$. The evidence for the presence of endemic LRSE clones that circulate in hospital settings was also reported $[10,12]$. These strains differ from commensal S. epidermidis isolates and become more successful in the hospital environment [6]. All isolates carried also the $i c a A D B C$ locus, which is responsible for the production of polysaccharide intercellular adhesin (PIA), playing an important role in formation of biofilm by the bacterium [52-53]. Since, the linezolid have been used to treat biofilmassociated S. epidermidis infections, the circulation of LRSE 
with a biofilm-associated operon constitutes a real threat for patients [54-55].

All studied isolates shared also the atypical composition of their SCCmec elements. Such situation is indeed observed in MRCoNS also by others $[3,56]$. Chen et al. showed the multiple ccr complexes composition in CoNS strains. The authors showed the ccrAB3 and $c c r A B 4$ genes in S. hominis and $S$. capitis [57]. Our study revealed not only the multiple $c c r$ but also a combination of SCCmec cassette II and III elements in all our LRSE strains. The detection of new SCCmec cassettes composition of all LRSE strains revealed the acquisition of antibiotic resistance determinants within hospital environment and revealed that CoNS strains are a reservoir of antibiotic resistance genes which can be easily spread to $S$. aureus strains. To fully elucidate the structure of SCCmec element in studied isolates, the wholegenome sequencing is indispensable.

In conclusion, we have reported the first emergence of LRSE in Poland. Recently, linezolid is used more frequently, especially in pediatric patients for treatment of severe infections. As the ST2 LRSE is identified not only in Poland but in many European countries, it is very important to start or continue the surveillance, infection control, and antimicrobial guidelines against linezolid-resistant staphylococcal strains.

Acknowledgments The publication made use of the PubMLST website (https://pubmlst.org/) developed by Keith Jolley (Jolley et al. Welcome Open Res 2018, 3:124) and sited at the University of Oxford. The development of that website was funded by the Welcome Trust. We thank Mariola Wolska for performing PCR of SCCmec cassettes during the study.

Funding information This project was partly financed by funds granted by the National Science Centre (NCN, Poland) on the basis of the decision no. UMO-2016/21/N/NZ6/00981 (for M.K.S.).

M.K.S. was financially supported by scholarship from the Leading National Research Center (KNOW) for Faculty of Biochemistry, Biophysics and Biotechnology Jagiellonian University, Krakow, which is supported by the Ministry of Science and Higher Education in Poland.

\section{Compliance with ethical standards}

Conflict of interest The authors declare that they have no conflict of interest.

Ethical approval For this type of study, formal consent is not required.

Open Access This article is licensed under a Creative Commons Attribution 4.0 International License, which permits use, sharing, adaptation, distribution and reproduction in any medium or format, as long as you give appropriate credit to the original author(s) and the source, provide a link to the Creative Commons licence, and indicate if changes were made. The images or other third party material in this article are included in the article's Creative Commons licence, unless indicated otherwise in a credit line to the material. If material is not included in the article's Creative Commons licence and your intended use is not permitted by statutory regulation or exceeds the permitted use, you will need to obtain permission directly from the copyright holder. To view a copy of this licence, visit http://creativecommons.org/licenses/by/4.0/.

\section{References}

1. Kosecka-Strojek M, Buda A, Miedzobrodzki J (2018) Staphylococcal ecology and epidemiology. In: Savini V (ed) Petto-man travelling staphylococci: a world in progress, 1 st edn. Elsevier, Cambridge, pp 11-24. https://doi.org/10.1016/B978-012-813547-1.00002-9

2. Sydnor ER, Perl TM (2011) Hospital epidemiology and infection control in acute-care settings. Clin Microbiol Rev 24(1):141-173. https://doi.org/10.1128/CMR.00027-10

3. Otto M (2013) Coagulase-negative staphylococci as reservoirs of genes facilitating MRSA infection: staphylococcal commensal species such as Staphylococcus epidermidis are being recognized as important sources of genes promoting MRSA colonization and virulence. Bioessays. 35(1):4-11. https://doi.org/10.1002/bies. 201200112

4. Liakopoulos V, Petinaki E, Efthimiadi G, Klapsa D, Giannopoulou M, Dovas S, Eleftheriadis T, Mertens PR, Stefanidis I (2008) Clonal relatedness of methicillin-resistant coagulase-negative staphylococci in the haemodialysis unit of a single university centre in Greece. Nephrol Dial Transplant 23(8):2599-2603. https://doi.org/10.1093/ ndt $/$ gfn 101

5. Cherifi S, Byl B, Deplano A, Nonhoff C, Denis O, Hallin M (2013) Comparative epidemiology of Staphylococcus epidermidis isolates from patients with catheter-related bacteremia and from healthy volunteers. J Clin Microbiol 51(5):1541-1547. https://doi.org/10. 1128/JCM.03378-12

6. Cherifi S, Byl B, Deplano A, Nagant C, Nonhoff C, Denis O, Hallin $M$ (2014) Genetic characteristics and antimicrobial resistance of Staphylococcus epidermidis isolates from patients with catheterrelated bloodstream infections and from colonized healthcare workers in a Belgian hospital. Ann Clin Microbiol Antimicrob 13:20. https://doi.org/10.1186/1476-0711-13-20

7. Deplano A, Vandendriessche S, Nonhoff C, Dodémont M, Roisin S, Denis O (2016) National surveillance of Staphylococcus epidermidis recovered from bloodstream infections in Belgian hospitals. J Antimicrob Chemother 71(7):1815-1819. https://doi.org/ 10.1093/jac/dkw086

8. Mendes RE, Deshpande LM, Jones RN (2014) Linezolid update: stable in vitro activity following more than a decade of clinical use and summary of associated resistance mechanisms. Drug Resist Updat 17:1-12

9. Tsiodras S, Gold HS, Sakoulas G, Eliopoulos GM, Wennersten C, Venkataraman L, Moellering RC, Ferraro MJ (2001) Linezolid resistance in a clinical isolate of Staphylococcus aureus. Lancet 358: 207-208

10. Barros M, Branquinho R, Grosso F, Peixe L, Novais C (2014) Linezolid-resistant staphylococcus epidermidis, Portugal, 2012. Emerg Infect Dis 20(5):903-905. https://doi.org/10.3201/eid2005. 130783

11. Bender J, Strommenger B, Steglich M, Zimmermann O, Fenner I, Lensing C, Dagwadordsch U, Kekule AS, Werner G, Layer F (2015) Linezolid resistance in clinical isolates of Staphylococcus epidermidis from German hospitals and characterization of two cfrcarrying plasmids. J Antimicrob Chemother 70(6):1630-1638. https://doi.org/10.1093/jac/dkv025

12. Karavasilis V, Zarkotou O, Panopoulou M, Kachrimanidou M, Themeli-Digalaki K, Stylianakis A, Gennimata V, Ntokou E, Stathopoulos C, Tsakris A, Pournaras S (2015) On behalf of the Greek Study Group on Staphylococcal Linezolid Resistance Wide dissemination of linezolid-resistant Staphylococcus epidermidis in Greece is associated with a linezolid-dependent ST22 clone. J Antimicrob Chemother 70(6):1625-1629. https://doi.org/10.1093/ jac/dkv028 
13. O'Connor C, Powell J, Finnegan C, O'Gorman A, Barrett S, Hopkins KL, Pichon B, Hill R, Power L, Woodford N, Coffey JC, Kearns A, O'Connell NH, Dunne CP (2015) Incidence, management and outcomes of the first cfr-mediated linezolid-resistant Staphylococcus epidermidis outbreak in a tertiary referral centre in the Republic of Ireland. J Hosp Infect 90(4):316-321. https://doi. org/10.1016/j.jhin.2014.12.013

14. Brenciani A, Morroni G, Pollini S, Tiberi E, Mingoia M, Varaldo PE, Rossolini GM, Giovanetti E (2016) Characterization of novel conjugative multiresistance plasmids carrying cfr from linezolidresistant Staphylococcus epidermidis clinical isolates from Italy. J Antimicrob Chemother 71(2):307-313. https://doi.org/10.1093/jac/ dkv341

15. Dortet L, Glaser P, Kassis-Chikhani N, Girlich D, Ichai P, Boudon M, Samuel D, Creton E, Imanci D, Bonnin R, Fortineau N, Naas T (2018) Long-lasting successful dissemination of resistance to oxazolidinones in MDR Staphylococcus epidermidis clinical isolates in a tertiary care hospital in France. J Antimicrob Chemother 73(1):41-51. https://doi.org/10.1093/jac/dkx370

16. Layer F, Vourli S, Karavasilis V, Strommenger B, Dafopoulou K, Tsakris A, Werner G, Pournaras S (2018) Dissemination of linezolid-dependent, linezolid-resistant Staphylococcus epidermidis clinical isolates belonging to CC5 in German hospitals. J Antimicrob Chemother 73(5):1181-1184. https://doi.org/10.1093/jac/dkx524

17. Weßels C, Strommenger B, Klare I, Bender J, Messler S, Mattner F, Krakau M, Werner G, Layer F (2018) Emergence and control of linezolid-resistant Staphylococcus epidermidis in an ICU of a German hospital. J Antimicrob Chemother 73(5):1185-1193. https://doi.org/10.1093/jac/dky010

18. Sadowy E (2018) Linezolid resistance genes and genetic elements enhancing their dissemination in enterococci and streptococci. Plasmid. 99:89-98. https://doi.org/10.1016/j.plasmid.2018.09.011

19. Ishiwada N, Takaya A, Kimura A, Watanabe M, Hino M, Ochiai H, Matsui M, Shibayama K, Yamamoto T (2016) Linezolid-resistant Staphylococcus epidermidis associated with long-term, repeated linezolid use in a pediatric patient. J Infect Chemother 22(3):187190. https://doi.org/10.1016/j.jiac.2015.10.004

20. Hill RL, Kearns AM, Nash J, North SE, Pike R, Newson T, Woodford N, Calver R, Livermore DM (2010) Linezolid-resistant ST36 methicillin-resistant Staphylococcus aureus associated with prolonged linezolid treatment in two paediatric cystic fibrosis patients. J Antimicrob Chemother 65(3):442-445. https://doi.org/10. 1093/jac/dkp494

21. Meka VG, Gold HS, Cooke A, Venkataraman L, Eliopoulos GM, Moellering RC Jr, Jenkins SG (2004) Reversion to susceptibility in a linezolid-resistant clinical isolate of Staphylococcus aureus. J Antimicrob Chemother 54(4):818-820

22. Liakopoulos A, Neocleous C, Klapsa D, Kanellopoulou M, Spiliopoulou I, Mathiopoulos KD, Papafrangas E, Petinaki E (2009) A T2504A mutation in the 23S rRNA gene responsible for high-level resistance to linezolid of Staphylococcus epidermidis. J Antimicrob Chemother 64(1):206-207. https://doi.org/10.1093/ $\mathrm{jac} / \mathrm{dkp} 167$

23. Lincopan N, de Almeida LM, Elmor de Araújo MR, Mamizuka EM (2009) Linezolid resistance in Staphylococcus epidermidis associated with a G2603 T mutation in the $23 \mathrm{~S}$ rRNA gene. Int $\mathrm{J}$ Antimicrob Agents 34(3):281-282. https://doi.org/10.1016/j. ijantimicag.2009.02.023

24. Cidral TA, Carvalho MC, Figueiredo AM, de Melo MC (2015) Emergence of methicillin-resistant coagulase-negative staphylococci resistant to linezolid with rRNA gene C2190T and G2603T mutations. APMIS. 123(10):867-871. https://doi.org/10.1111/apm. 12426

25. Gu B, Kelesidis T, Tsiodras S, Hindler J, Humphries RM (2013) The emerging problem of linezolid-resistant Staphylococcus. J
Antimicrob Chemother 68(1):4-11. https://doi.org/10.1093/jac/ dks354

26. Mendes RE, Deshpande LM, Farrell DJ, Spanu T, Fadda G, Jones RN (2010) Assessment of linezolid resistance mechanisms among Staphylococcus epidermidis causing bacteraemia in Rome, Italy. J Antimicrob Chemother 65(11):2329-2335. https://doi.org/10.1093/ $\mathrm{jac} / \mathrm{dkq} 331$

27. Fan R, Li D, Wang Y, He T, Feßler AT, Schwarz S, Wu C (2016) Presence of the optrA gene in methicillin-resistant Staphylococcus sciuri of porcine origin. Antimicrob Agents Chemother 60(12): 7200-7205

28. Antonelli A, D'Andrea MM, Brenciani A, Galeotti CL, Morroni G, Pollini S, Varaldo PE, Rossolini GM (2018) Characterization of poxtA, a novel phenicol-oxazolidinone-tetracycline resistance gene from an MRSA of clinical origin. J Antimicrob Chemother 73(7): 1763-1769. https://doi.org/10.1093/jac/dky088

29. Mendes RE, Deshpande LM, Castanheira M, DiPersio J, Saubolle MA, Jones RN (2008) First report of cfr-mediated resistance to linezolid in human staphylococcal clinical isolates recovered in the United States. Antimicrob Agents Chemother 52(6):2244 2246. https://doi.org/10.1128/AAC.00231-08

30. Seral C, Sáenz Y, Algarate S, Duran E, Luque P, Torres C, Castillo FJ (2011 Apr) Nosocomial outbreak of methicillin- and linezolidresistant Staphylococcus epidermidis associated with catheterrelated infections in intensive care unit patients. Int $\mathrm{J}$ Med Microbiol 301(4):354-358. https://doi.org/10.1016/j.ijmm.2010. 11.001

31. Lozano C, Ruiz-García M, Gómez-Sanz E, López-García P, RoyoGarcía G, Zarazaga M, Torres C (2012) Characterization of a cfrpositive methicillin-resistant Staphylococcus epidermidis strain of the lineage ST22 implicated in a life-threatening human infection. Diagn Microbiol Infect Dis 73(4):380-382. https://doi.org/10.1016/ j.diagmicrobio.2012.04.013

32. Woo PC, Leung AS, Leung KW, Yuen KY (2001) Identification of slide coagulase positive, tube coagulase negative Staphylococcus aureus by $16 \mathrm{~S}$ ribosomal RNA gene sequencing. Mol Pathol 54(4): 244-247

33. Bukowski M, Polakowska K, Ilczyszyn WM, Sitarska A, Nytko K, Kosecka M, Miedzobrodzki J, Dubin A, Wladyka B (2015) Species determination within Staphylococcus genus by extended PCRrestriction fragment length polymorphism of saoC gene. FEMS Microbiol Lett 362(1):1-11. https://doi.org/10.1093/femsle/fnu007

34. Kondo Y, Ito T, Ma XX, Watanabe S, Kreiswirth BN, Etienne J, Hiramatsu K (2007) Combination of multiplex PCRs for staphylococcal cassette chromosome mec type assignment: rapid identification system for mec, ccr, and major differences in junkyard regions. Antimicrob Agents Chemother 51(1):264-274. https://doi.org/10. 1128/AAC.00165-06

35. Linhardt F, Ziebuhr W, Meyer P, Witte W, Hacker J (1992) Pulsedfield gel electrophoresis of genomic restriction fragments as a tool for the epidemiological analysis of Staphylococcus aureus and coagulase-negative staphylococci. FEMS Microbiol Lett 74(2-3): $181-185$

36. Thomas JC, Vargas MR, Miragaia M, Peacock SJ, Archer GL, Enright MC (2007) Improved multilocus sequence typing scheme for Staphylococcus epidermidis. J Clin Microbiol 45(2):616-619. https://doi.org/10.1128/JCM.01934-06

37. Jolley KA, Bray JE, Maiden MCJ. (2018) Open-access bacterial population genomics: BIGSdb software, the PubMLST.org website and their applications. Wellcome Open Res 3:124. https:// doi.org/10.12688/wellcomeopenres.14826.1

38. Milheiriço C, Oliveira DC, de Lencastre H (2007 Sep) Update to the multiplex PCR strategy for assignment of mec element types in Staphylococcus aureus. Antimicrob Agents Chemother 51(9): 3374-3377 
39. Gawryszewska I, Żabicka D, Hryniewicz W, Sadowy E (2017) Linezolid-resistant enterococci in polish hospitals: species, clonality and determinants of linezolid resistance. Eur J Clin Microbiol Infect Dis 36(7):1279-1286. https://doi.org/10.1007/ s10096-017-2934-7

40. Leelaporn A, Yodkamol K, Waywa D, Pattanachaiwit S (2008) A novel structure of Tn4001-truncated element, type V, in clinical enterococcal isolates and multiplex PCR for detecting aminoglycoside resistance genes. Int J Antimicrob Agents 31(3):250-254

41. Sadowy E, Sieńko A, Gawryszewska I, Bojarska A, Malinowska K, Hryniewicz W (2013) High abundance and diversity of antimicrobial resistance determinants among early vancomycin-resistant Enterococcus faecium in Poland. Eur J Clin Microbiol Infect Dis 32(9):1193-1203. https://doi.org/10.1007/s10096-013-1868-y

42. Kosecka-Strojek M, Sabat AJ, Akkerboom V, Becker K, van Zanten E, Wisselink G, Miedzobrodzki J, Kooistra-Smid AMDM, Friedrich AW (2019) Development and validation of a reference data set for assigning Staphylococcus species based on nextgeneration sequencing of the 16S-23S rRNA region. Front Cell Infect Microbiol 9:278. https://doi.org/10.3389/fcimb.2019.00278

43. Sabat AJ, van Zanten E, Akkerboom V, Wisselink G, van Slochteren K, de Boer RF, Hendrix R, Friedrich AW, Rossen JWA, Kooistra-Smid AMDM (2017) Targeted next-generation sequencing of the 16S-23S rRNA region for culture-independent bacterial identification - increased discrimination of closely related species. Sci Rep 7(1):3434. https://doi.org/10.1038/s41598-01703458-6

44. Long KS, Poehlsgaard J, Kehrenberg C, Schwarz S, Vester B (2006) The Cfr rRNA methyltransferase confers resistance to phenicols, lincosamides, oxazolidinones, pleuromutilins, and streptogramin A antibiotics. Antimicrob Agents Chemother 50(7): 2500-2505

45. Magiorakos AP, Srinivasan A, Carey RB, Carmeli Y, Falagas ME, Giske CG, Harbarth S, Hindler JF, Kahlmeter G, Olsson-Liljequist B, Paterson DL, Rice LB, Stelling J, Struelens MJ, Vatopoulos A, Weber JT, Monnet DL (2012) Multidrug-resistant, extensively drug-resistant and pandrug-resistant bacteria: an international expert proposal for interim standard definitions for acquired resistance. Clin Microbiol Infect 18(3):268-281. https://doi.org/10. 1111/j.1469-0691.2011.03570.x

46. Miragaia M, Thomas JC, Couto I, Enright MC, de Lencastre H (2007) Inferring a population structure for Staphylococcus epidermidis from multilocus sequence typing data. J Bacteriol 189(6):2540-2552

47. Frickmann H, Gawlik PP, Crusius S, Podbielski A (2012) The current role of pulsed-field gel electrophoresis in methicillin-resistant Staphylococcus aureus (MRSA) typing and the retrospective identification of outbreaks. Eur J Microbiol Immunol (Bp) 2(2):128133. https://doi.org/10.1556/EuJMI.2.2012.2.5

48. Long KS, Vester B (2012) Resistance to linezolid caused by modifications at its binding site on the ribosome. Antimicrob Agents Chemother 56(2):603-612. https://doi.org/10.1128/AAC.05702-11
49. Rouard C, Aslangul E, Rivière A, Deback C, Butel MJ, DoucetPopulaire F, Bourgeois-Nicolaos N (2017) Mutation in the L3 ribosomal protein could be associated with risk of selection of highlevel linezolid-resistant Staphylococcus epidermidis strains. Microb Drug Resist 23(4):462-467. https://doi.org/10.1089/mdr.2016. 0137

50. Cercenado E et al (2010) Emerging linezolid resistance: dissemination of the cfr gene among Staphylococcus aureus, Staphylococcus epidermidis, enterococcus faecium and enterococcus faecalis and inability of the Etest method for detection, abstr C2-1490. Abstr. 50th Intersci. Conf. Antimicrob. Agents Chemother., Boston, MA

51. Locke JB, Finn J, Hilgers M, Morales G, Rahawi S, G C K, Picazo JJ, Im W, Shaw KJ, Stein JL (2010) Structure-activity relationships of diverse oxazolidinones for linezolid-resistant Staphylococcus aureus strains possessing the $\mathrm{cfr}$ methyltransferase gene or ribosomal mutations. Antimicrob Agents Chemother 54(12):5337-5343. https://doi.org/10.1128/AAC.00663-10

52. Heilmann C, Schweitzer O, Gerke C, Vanittanakom N, Mack D, Götz F (1996) Molecular basis of intercellular adhesion in the biofilm-forming Staphylococcus epidermidis. Mol Microbiol 20: 1083-1091

53. Ziebuhr W, Heilmann C, Götz F, Meyer P, Wilms K, Straube E, Hacker J (1997) Detection of the intercellular adhesion gene cluster (ica) and phase variation in Staphylococcus epidermidis blood culture strains and mucosal isolates. Infect Immun 65:890-896

54. Hashem AA, Abd E, Fadeal NM, Shehata AS (2017) In vitro activities of vancomycin and linezolid against biofilm-producing methicillin-resistant staphylococci species isolated from catheterrelated bloodstream infections from an Egyptian tertiary hospital. J Med Microbiol 66(6):744-752. https://doi.org/10.1099/jmm.0. 000490

55. Reiter KC, Villa B, Paim TG, de Oliveira CF, d'Azevedo PA (2013) Inhibition of biofilm maturation by linezolid in meticillin-resistant Staphylococcus epidermidis clinical isolates: comparison with other drugs. J Med Microbiol 62(Pt 3):394-399. https://doi.org/10.1099/ jmm.0.048678-0

56. Hanssen AM, Ericson Sollid JU (2007) Multiple staphylococcal cassette chromosomes and allelic variants of cassette chromosome recombinases in Staphylococcus aureus and coagulase-negative staphylococci from Norway. Antimicrob Agents Chemother 51: 1671-1677

57. Chen XP, Li WG, Zheng H, Du HY, Zhang L, Zhang L, Che J, Wu Y, Liu SM, Lu JX (2017 Aug 22) Extreme diversity and multiple SCCmec elements in coagulase-negative Staphylococcus found in the clinic and Community in Beijing, China. Ann Clin Microbiol Antimicrob 16(1):57. https://doi.org/10.1186/s12941-017-0231-z

Publisher's note Springer Nature remains neutral with regard to jurisdictional claims in published maps and institutional affiliations. 